$\xi=-1$

\title{
Laundry Detergent Compatibility of Papain Like Protease Purified From Piper Betel Leaves
}

\author{
A. Mousami Shankar ${ }^{1}$, Dr. G.V.D. Sirisha ${ }^{2}$, Dr. K. Vijaya Rachel ${ }^{3 *}$ \\ ${ }^{1}$ research Fellow, ${ }^{2}$ lecturer, ${ }^{3 *}$ Associate Professor \\ ${ }^{1}$ Research Fellow, Central Technological Research Institute, Mysore, Karnataka, India. \\ ${ }^{2 \& 3 *}$ Department Of Biochemistry, Institute Of Science, Gitam University, Visakhapatnam - 530 045, India. \\ *Corresponding Author E-Mail: Rachelr68@Gmail.Com
}

\begin{abstract}
Enzymes have wide applications in detergent industry from early 1900's. Mostly, clothes are soiled by protein based grime. Most of the detergents have either amylase / protease. Various sources were scrutinized for potent protease activity and Betel leaves were selected, the enzyme was then isolated, purified to homogeneity by ammonium sulphate precipitation, DEAE-Cellulose and gel permeation chromatographic techniques. The enzyme was monomeric in nature with a molecular mass of $38 \mathrm{kDa}$ as determined by native PAGE and SDS-PAGE. The enzyme shows maximum activity at $60^{\circ} \mathrm{C}$ and $\mathrm{pH} 4.0$. The $\mathrm{Km}$ and $\mathrm{Vmax}$ of the enzyme were $4 \times 10^{-3} \mathrm{M}$ and $54 \mu \mathrm{mol} / \mathrm{min} / \mathrm{mg}$ respectively. The enzyme was categorically inhibited by PCMB and iodo-acetamide suggesting it to have papain like nature. The stability of the enzyme is assessed over the stretch of alkaline $\mathrm{pH}$ and temperature. This evaluation validates the stability of the enzyme and its use in detergent formulations. It was evident that after adding the enzyme preparation the stains (tea, chocolate, blood) were removed much better than that of the controls, which affirms that papain like enzyme from betel leaves, enhances detergent activity.
\end{abstract}

Keywords: Betel Leaves; Detergent Activity ; Enzyme Kinetics; Purification.

\section{Introduction}

An ideal cleansing product claims to remove stains faster, easier, at any temperature and with minimal water usage. Synthetic and organic surfactants decrease surface tension of water and their use in detergents facilitates removal of grease and dirt. Earlier, detergents were manufactured considering grime on clothing as protein based. Presently, every detergent is fortified with an amylase or a protease.

The knowledge of using proteases in industry, specifically as detergents dates back to 1913 where pancreatic extracts were used by Roehm. Ease of use of bacterial enzymes in 1960s, made their employability efficient in technical as well as economic sense. These enzymes were initially produced using Bacillus species, especially with Bacillus amyloliquefaciens and Bacillus licheniformis. Their alkaline proteases represent the lead molecules for subtilisins [1]. The action of proteases, as implied by the name itself, hydrolyzes large protein molecules. Owing to the process of hydrolysis, smaller peptides and amino acids are released due to the breaking of peptide bonds that hold amino acids together to form a protein [2]. The family of peptide-bond cleaving hydrolases, the peptidases/ proteases, can be categorized as endopeptidases and exopeptidases according to the breaking point in the peptide chain. These enzymes can be classified further, according to the reactive groups at the active site involved in catalysis, into serine, cysteine, aspartic and metalloendopeptidases. The proteases of serine and cysteine groups have been thoroughly studied and are the best characterized subgroups.
Papain is a cysteine protease on which extensive research was done and displays stability and activity under a wide range of conditions. It is highly stable even at higher temperatures [3]. The sequence and three-dimensional structure of papain [4-7] are known. The latex of Carica papaya is a rich source of Papain. Its utility in hydrolyzing tough meat fibers was practiced for thousands of years in South America. Papain as teeth-whitener is a constituent in some dentifrice or mints [8]. Papacarie a gel with key ingredient of papain is utilized for chemo-mechanical dental caries. The diversified use of papain validates it to be an exceedingly valued enzyme. Betel leaves exhibit high protease activity. The decoction of the leaves is used to cure indigestion, constipation and also as a decongestant. Literature reveals it to interfere with urine drug test for cannabinoids [9]. Its presence is detected in few drug detoxification products. So in this study the papain like enzyme was isolated from betel leaves, purified and characterized. Further its effectiveness as a detergent was studied.

\section{Materials \& Method}

Papaya leaves, papaya ripen fruit, papaya unripe fruit, barley seeds and betel leaves were collected from local markets of Visakhapatnam in Andhra Pradesh. Leaves and fruits are used in fresh condition.

\subsection{Chemicals Used}

Bovine pancreatic trypsin, bovine pancreatic $\alpha$-chymotrypsin, pronase, papain, pepsin, thermolysin, $\alpha$-amylase, DEAE-cellulose, SephadexG-100, acrylamide, bis-acrylamide, TEMED, Ammoni- 
um persulphate, SDS, protein markers. 18 cloth sections, Chocolate, tea, blood samples for making stains, $1 \mathrm{ml}$ of liquid laundry detergent containing enzymes (commercial brand name Tide), $1 \mathrm{ml}$ liquid laundry detergent without enzymes (commercial brand name surf), $1 \mathrm{ml}$ of liquid laundry detergent containing oxy power (commercial brand henko). Different normalities of $\mathrm{NaCl}$, citratephosphate buffer ( $\mathrm{pH} 4$ ), phosphate buffer ( $\mathrm{pH} 5-8$ ), Carbonate buffer ( $\mathrm{pH}$ 9-10) were used. Chemicals of analytical grade were used.

\subsection{Preparation of Source extract:}

10gms of fresh source (papaya fruit, papaya leaves, barley seeds, betel leaves individually) were taken. They were crushed and ground using motor and pestle with $100 \mathrm{ml}$ of $0.1 \mathrm{M}$ phosphate buffer ( $\mathrm{pH}$ 7.6). The extract was centrifuged at 10,000rpm for $15 \mathrm{mins}$ at $4^{\circ} \mathrm{C}$. The precipitate was rejected and supernatant was taken for estimation of protease activities.

\subsection{Estimation of pepsin activity:}

All Anson's method was used for estimation of pepsin activity [10] using denatured hemoglobin as substrate. One $\mathrm{ml}$ of $1 \mathrm{mM} \mathrm{HCL}$ containing $30 \mu \mathrm{g}$ of pepsin was incubated with $1 \mathrm{ml}$ of hemoglobin solution (20mg per $\mathrm{ml}$ in $0.06 \mathrm{~N} \mathrm{HCL}$ ) at $37^{\circ} \mathrm{C}$ for $10 \mathrm{mins}$ and addition of $2 \mathrm{ml}$ of $10 \%$ TCA arrested the reaction. The solution was filtered and the surge in the absorbance over the controls at $280 \mathrm{~nm}$ was considered as an index of the proteolysis.

\subsection{Estimation of trypsin activity:}

Trypsin activity was estimated using casein as a substrate. Caseinolytic activity of trypsin was determined by the casein digestion method according to Liener and Kakade [11]. To 3ml of trypsin solution $(50 \mu \mathrm{g}$ in $100 \mathrm{mM}$ sodium phosphate buffer, $\mathrm{pH} 7.6)$ $2 \mathrm{ml}$ of $1 \%$ casein solution in phosphate buffer, $\mathrm{pH} 7.6$ was added. After incubation at $37^{\circ} \mathrm{C}$ for $20 \mathrm{~min}$, addition of $5 \mathrm{ml}$ of $5 \% \mathrm{TCA}$ arrested the reaction. The solution was filtered after standing for $1 \mathrm{hr}$ at room temperature and the absorbance of the filtrate was measured at $280 \mathrm{~nm}$ in Hitachi spectrophotometer against a blank. Addition of TCA to the incubation mixture before the addition of casein is required to prepare a blank.

\subsection{Estimation of chymotrypsin activity:}

Chymotrypsin activity was estimated using casein as a substrate. Chymotrypsin was dissolved in $1 \mathrm{mM} \mathrm{HCl}$ containing $20 \mathrm{mM}$ $\mathrm{CaCl}_{2}$ to obtain a concentration of $100 \mu \mathrm{g}$ per ml. To $3 \mathrm{ml}$ of chymotrypsin solution ( $40 \mu \mathrm{g}$ in $100 \mathrm{mM}$ sodium phosphate buffer), $2 \mathrm{ml}$ of $1 \%$ casein solution in phosphate buffer, $\mathrm{pH} 7.6$ was added After incubation at $37^{\circ} \mathrm{C}$ for $10 \mathrm{~min}$, the reaction was stopped by addition of $5 \mathrm{ml}$ of $5 \%$ TCA. The precipitate was filtered after standing for $1 \mathrm{hr}$ at room temperature and the absorbance of the filtrate was read at $280 \mathrm{~nm}$ in Hitachi spectrophotometer against a blank prepared by adding TCA to the incubation mixture prior to the addition of casein.

\subsection{Estimation of Papain Activity:}

Papain was assayed for its activity against casein as substrate [12] The enzyme was activated with $50 \mathrm{mM}$ cysteine and $20 \mathrm{mM}$ EDTA $1 \mathrm{ml}$ of activated papain $(50 \mu \mathrm{g}$ in $100 \mathrm{mM}$ Tris-HCL buffer, $\mathrm{pH} 8.0)$ was mixed with $1 \mathrm{ml}$ of $1 \%$ casein solution in Tris-HCL buffer $(\mathrm{pH}$ 8.0 ) and incubated at $37^{\circ} \mathrm{C}$ for $10 \mathrm{~min}$. The reaction was inactivated by adding $3 \mathrm{ml}$ of $5 \%$ TCA. The precipitate was filtered after standing for $1 \mathrm{hr}$ at room temperature and the absorbance was read at $280 \mathrm{~nm}$ in Hitachi spectrophotometer against a blank. Addition of TCA to the incubation mixture before the addition of casein is required to prepare a blank.

\subsection{Purification of isolated enzyme:}

\subsubsection{Ammonium Sulphate Precipitation and Dialysis:}

Homogenate was taken and subjected to ammonium sulphate precipitation at different concentrations (40\%-100\%). Then the supernatant and the pellet were assayed for papain activity and the fraction showing highest activity was further purification was carried out by dialysis.

\subsubsection{Ion-Exchange Chromatography:}

Ion-Exchange chromatography was used to purify the dialyzed sample. $2 \mathrm{ml}$ fractions were collected into different test tubes using $0.1 \mathrm{~N}-1.0 \mathrm{~N} \mathrm{NaCl}$ ionic gradient. The absorbance of the collected fractions was measured by spectrophotometer at $280 \mathrm{~nm}$. The fractions were assayed for papain like activity and further purified by gel permeation.

\subsubsection{Gel permeation Chromatography:}

The selected fractions from ion exchange chromatography were purified by gel permeation chromatography using Sephadex G-100. Homogeneity of the selected fractions were visualised by PAGE. Para Chloro Mercuric Benzomate (PCMB) was used as an inhibitor of papain enzyme. $1 \mathrm{ml}$ of PCMB was mixed with fractions and incubated for $1 \mathrm{~min}$ then $2 \mathrm{ml}$ of substrate i.e. $1 \%$ casein was mixed and incubated for $10 \mathrm{~min}$ at $37^{\circ} \mathrm{C}$. Then treated with $5 \mathrm{ml}$ of TCA and denatured reaction mixture was filtered. Now the activity was read in a spectrophotometer at $280 \mathrm{~nm}$. The fractions exhibiting no activity were selected and further characterized.

\subsubsection{SDS-PAGE:}

SDS-Polyacrylamide gel electrophoresis was performed by the method of Laemmli [13] in 12\% slab gels. Phosphorylase-b (97.4 $\mathrm{KDa})$, serum albumin (66K Da), ovalbumin (43kDa), carbonic anhydrase (29K Da), lysozyme (14.3K Da) and commercial papain were used as protein markers. A standard curve was plotted with the distance travelled by the standard proteins against their $\log$ molecular weights. The molecular weight of unknown protein was read from calibration curve.

\subsection{Enzyme Kinetics of Isolated Enzyme:}

The purified enzyme obtained was used for analysing Time course, Enzyme concentration, Temperature, $\mathrm{pH}$ and Substrate concentration.

\subsubsection{Effect of Time Course on Enzyme Activity:}

$1 \mathrm{ml}$ of casein substrate was incubated with $1 \mathrm{ml}$ of enzyme. The reaction was arrested with the addition of $5 \mathrm{ml}$ of $10 \%$ TCA at regular intervals i.e., $0,5,10,15,20,25,30,60 \mathrm{~min}$ and the filtrate was checked for papain activity using spectrophotometer.

\subsubsection{Effect of pH on Enzyme Activity:}

$1 \mathrm{ml}$ each of buffered casein and enzyme were taken in a series of test tubes at $\mathrm{pH}$ ranging from 4-10. Then it was incubated for $10 \mathrm{~min}$ at $37^{\circ} \mathrm{C}$. Then the reaction was terminated with addition of $5 \mathrm{ml}$ of $10 \%$ TCA. The filtrate was checked for enzyme activity using spectrophotometer.

\subsubsection{Effect of Temperature on Enzyme Activity:}

$1 \mathrm{ml}$ of $2 \%$ casein substrate was pre-incubated at $25^{\circ} \mathrm{C}, 30^{\circ} \mathrm{C}, 40^{\circ} \mathrm{C}$ $50^{\circ} \mathrm{C}$ and $60^{\circ} \mathrm{C}$. $1 \mathrm{ml}$ of enzyme was mixed and incubated for $10 \mathrm{~min}$ at respective temperatures. $5 \mathrm{ml}$ of $10 \%$ TCA was added to arrest the reaction. The filtrate was checked for enzyme activity using spectrophotometer.

2.8.4. Effect of Enzyme Concentration on Enzyme activity: 
$1 \mathrm{ml}$ of $2 \%$ casein solution was taken as substrate and enzyme concentrations as $0.1,0.2,0.3,0.4,0.5 \mu \mathrm{g} / \mathrm{ml}$ respectively. $5 \mathrm{ml}$ of $10 \%$ TCA was added to arrest the reaction after 10min of incubation. The filtrate was checked for enzyme activity using spectrophotometer.

\subsubsection{Effect of substrate concentration on enzyme activity:}

$0.1,0.2,0.3,0.4$ and $0.5 \mathrm{ml}$ of $2 \%$ casein was taken in different test tubes and the final volume was made up to $1 \mathrm{ml}$ using phosphate buffer for papaya leaves and carbonate-phosphate buffer for betel leaves. $5 \mathrm{ml}$ of $10 \%$ TCA was added to arrest the reaction after 10min of incubation. The filtrate was checked for papain activity using spectrophotometer.

\subsubsection{Michaelis-Menten kinetics:}

Varying concentrations of buffered substrate $(0.005$ to $0.02 \mu$ moles $)$ were incubated for $10 \mathrm{mins}$ at $37^{\circ} \mathrm{C}$. After incubation $0.5 \mathrm{ml}$ of enzyme was added and incubated at identical temperature for $30 \mathrm{~min}$. Then the papain activity was arrested using TCA. The absorbance of the filtrate from each test tube was measured at $280 \mathrm{~nm}$ against a blank prepared without the enzyme. The enzyme activity at each substrate concentration was estimated and M-M constant was resolved by plotting $1 / \mathrm{v}$ vs. $1 /[\mathrm{s}]$.

\subsection{Detergent Activity of Papain like Enzyme:}

The detergent activity of papain like enzyme isolated from the betel leaves was found by the following procedure:

A white populine cloth was taken and scissored into 18 equal squares one day before the experiment. All 18 squares were scissored from the same cloth to avoid variables like brand and fiber content. The cut cloth pieces were tainted with chocolate, tea, and blood stains. Clothes were allowed to sit overnight. On second day, enzyme solution was prepared by dissolving $1 \mathrm{gm}$ of papain like enzyme in $100 \mathrm{ml}$ of water. $300 \mathrm{ml}$ of ordinary tap water was measured and poured into 18 clean $500 \mathrm{ml}$ glass beakers each. Beakers were marked conferring to the respective stain. 6 beakers were employed for cleaning each stain. Tide, Henko, Surf were considered for cleaning the respective stain in the absence or presence of the enzyme. The stained cloths in each beaker were mixed well using a glass rod for every 10minutes up to a time period of 2 hours. After 2 hours each stained cloth soaked in the respective detergent was washed with water, and observed for the presence or absence of stains.

\section{Results and Discussion}

In The papain like enzyme from Betel leaves was partially characterized and assessed for its compatibility with powder detergents.

\subsection{Screening of Various Sources for Protease Activity:}

Papain, pepsin, chymotrypsin, trypsin and amylase activities were determined in four different sources namely Papaya ripen fruit, Papaya unripe fruit, Papaya leaves, Barley seeds and Betel leaves as mentioned in table 1 .

Table 1: Determination of proteases activities in different sources

\begin{tabular}{|c|c|c|c|c|}
\hline Sources & $\begin{array}{c}\text { Pepsin activity } \\
\mathrm{mg} / \mathrm{ml}\end{array}$ & $\begin{array}{c}\text { Trypsin activity } \\
\mathrm{mg} / \mathrm{ml}\end{array}$ & $\begin{array}{c}\text { Papain activity } \\
\mathrm{mg} / \mathrm{ml}\end{array}$ & $\begin{array}{c}\text { Chymotrypsin } \\
\text { activity mg/ml }\end{array}$ \\
\hline Standard & 0.072 & 0.045 & 0.197 & 1.112 \\
\hline Papaya ripen fruit & 0.109 & 0.034 & 0.104 & 0.034 \\
\hline Papaya unripe fruit & 0.018 & 0.028 & 0.058 & 0.016 \\
\hline Papaya leaves & 0.0170 & 0.025 & 0.020 & 0.413 \\
\hline Bareley seeds & 0.115 & 0.012 & 0.015 & 0.025 \\
\hline Betel leaves & 0.076 & 0.030 & 0.109 & 0.052 \\
\hline
\end{tabular}

Among these betel leaves, exhibited highest papain activity. According to literature papaya was documented for its papain activity [14]. But in our present study betel leaves exhibited more papain activity. So, further studies were carried out using purified papain like enzyme from betel leaves.

\subsection{Isolation of papain like enzyme from betel Leaves:}

The betel leaf homogenate subjected to ammonium sulphate fractionation exhibited highest activity at $40 \%$ precipitation. The pellet was suspended in carbonate-phosphate buffer and was dialyzed against the buffer for several times. Ion exchange chromatography was employed after dialysis and the results are depicted in figure 1. Fractions showing maximum absorption were further assayed for papain activity. Fractions 66-68 and 70-72 exhibited papain activity.

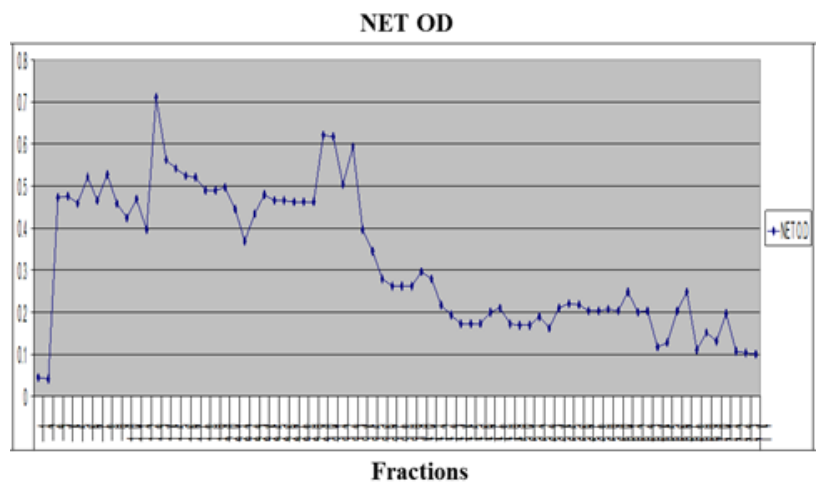

Fig. 1: Ion exchange chromatography of papain like protease from betel leaves on DEAE-Cellulose

Ammonium sulphate fractionated sample $(0-50 \%)$ was applied on to the column $(1.8 \times 30 \mathrm{~cm})$ in 0.2 $\mathrm{M}$ carbonate-phosphate buffer $(\mathrm{pH} 4)$ and the adsorbed proteins were eluted with stepwise gradien in the buffer. $60 \mathrm{ml}$ per hour flow rate was employed with collection of $2 \mathrm{ml}$ fractions. The protein was examined by measuring the absorbance at $280 \mathrm{~nm}$.

These fractions were pooled and further purified by gel permeation chromatography. A single peak was visualized in figure 2 a single peak which was further checked for papain activity. The activity of the purified enzyme was confirmed by inhibitory binding studies using PCMB (Para Chloro Mercuric Benzoate) a specific inhibitor of papain. When the isolated enzyme was treated with PCMB, activity was not identified showing that the isolated enzyme has papain activity.

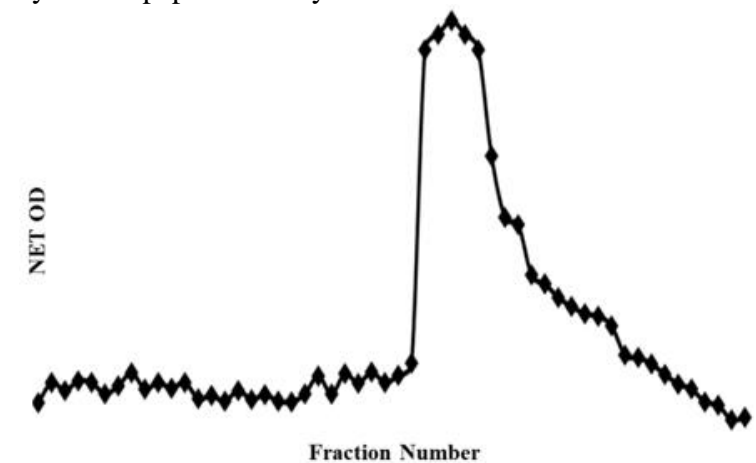

Fig. 2: Gel permeation chromatogram

Elution profile of Papain like protease on a calibrated column of Sephadex G-150. 10gm of purified Papain like Protease was loaded on the column in Carbonate- Phosphate buffer $\mathrm{pH} 4$ containing $20 \mathrm{mM} \mathrm{Nacl}$ and eluted with same buffer. Fractions of $2 \mathrm{ml}$ each were collected at flow rate of $12 \mathrm{ml}$ per hour. Protein was monitered at $280 \mathrm{~nm}$.

Homogeneity of the isolated enzyme was further confirmed by single broad protein band on native PAGE as depicted in figure 3. 


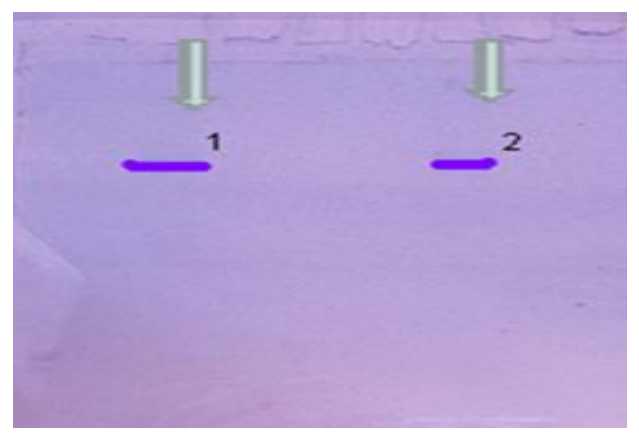

Fig. 3: Polyacrylamide Gel Electrophoresis

Direction of migration is from top(cathode) to bottom (anode)

1. Papain standard; 2. Isolated Papain like enzyme from Betel leaves.

The papain like enzyme treated with SDS showed a single coommassie blue stained, protein band corresponding to a molecular weight of $38 \mathrm{kDa}$ as depicted in figure 4 . The relative mobility of papain like enzyme to that of standard marker proteins i.e., Phosphorylase-b (97.4 kDa), serum albumin (66 kDa), ovalbumin (43 kDa), Carbonic anhydrase (29 kDa), and lysozyme (14.3 kDa) was used to identify the protein.

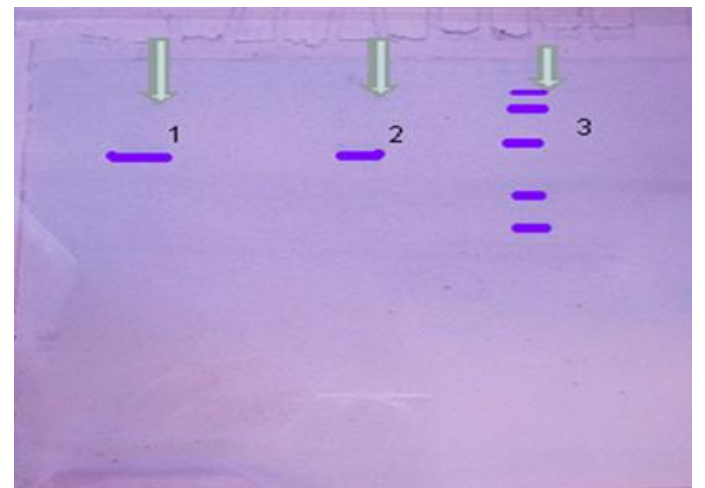

Fig. 4: Detection of Papain like Protease using SDS -PAGE

Direction of migration is from top(cathode) to bottom (anode)

1. Papain standard; 2. Isolated Papain like enzyme from Betel leaves; 3.Molecular weight markers: Phosphorylaseb(97.4kDa), BSA(66kDa) Ovalabumin(43kDa), Carbonic Anhydrase -(29kDa), Lysozyme(14.3 kDa)

A standard curve was constructed by plotting the distance travelled by the standard proteins against their log molecular weights (figure 5). Papain was described as a single band with molecular weight of $38.9 \mathrm{kDa}[15]$. The purified enzyme band is $38.5 \mathrm{kDa}$ as against that shown in the literature. This also validates that the purified enzyme is probably papain.

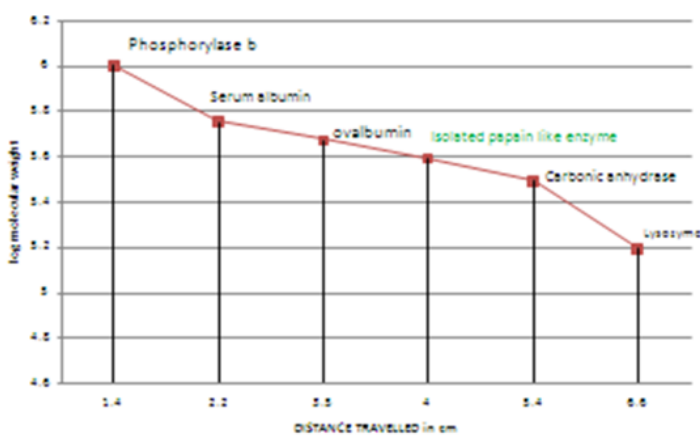

Fig. 5: Molecular weight determination of the isolated papain like protease from Betel leaves by SDS-PAGE on $12 \%$ slab gel

Plot of distance migrated against log molecular weight of standard proteins Phosphorylase-b - 97.4kDa; BSA - 66kDa; Ovalabumin - 43kDa; Carbonic Anhydrase - 29kDa; Lysozyme - $14.3 \mathrm{kDa}$
The papain-like enzyme from betel leaves showed maximum activity at 45 minutes as depicted in figure 6.

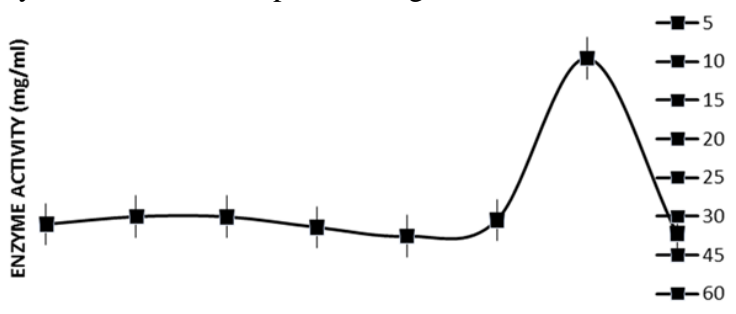

TIME COURSE (minutes)

Fig. 6: Effect of Time on enzyme activity

Effect of Time on the papain like protease purified from betel leaves was done at different time intervals 5,10,15,20,25,30,45,60 minutes. Maximum activity was found at $45 \mathrm{mins}$.

\subsection{Effect of pH and Temperature on Enzyme Activity:}

The $\mathrm{pH}$ and temperature maxima for betel leaves were 10 and $60^{\circ} \mathrm{C}$ (figure $7 \& 8$ ). According to literature, $\mathrm{pH}$ and temperature optima are reported to be species specific and vary between 4-10 and $25-60^{\circ} \mathrm{C}$ respectively for proteases from other sources [16]. The alkaline nature of the purified enzyme finds good application in detergent formulations as it matches with the basicity of water.

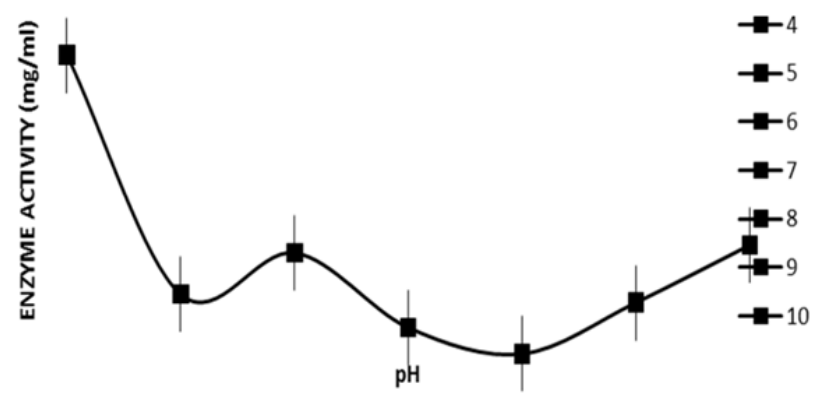

Fig. 7: Effect of $\mathrm{pH}$ on enzyme activity

Effect of $\mathrm{pH}$ on the papain like protease purified from betel leaves was done using buffers at different $\mathrm{pH}$ ranging from 4-10. Maximum activity was found with carbonate-phosphate buffer at $\mathrm{pH}$

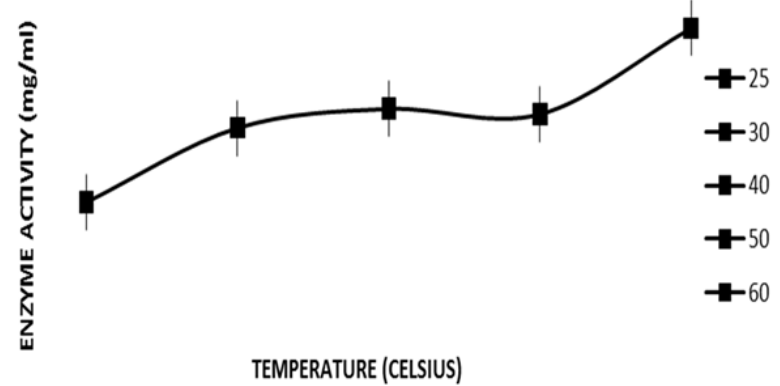

Fig. 8: Effect of Temperature on enzyme activity

Effect of temperature on the papain like protease purified from betel leaves was done at $25,30,40,50,60^{\circ} \mathrm{C}$. Maximum activity was at $60^{\circ} \mathrm{C}$.

\subsection{Effect of Enzyme and Substrate Concentration on Enzyme Activity:}

Among the different enzyme concentrations $(0.1-0.5 \mathrm{mg} / \mathrm{ml})$ studied highest papain activity was identified at an enzyme concentration of $0.4 \mathrm{mg} / \mathrm{ml}$ for betel leaves (figure 9). By using different casein concentrations $(0.5-2.5 \mathrm{mg} / \mathrm{ml})$ in the reaction mixture, maximum papain activity was determined to be $2.5 \mathrm{mg} / \mathrm{ml}$ (figure $10)$. 


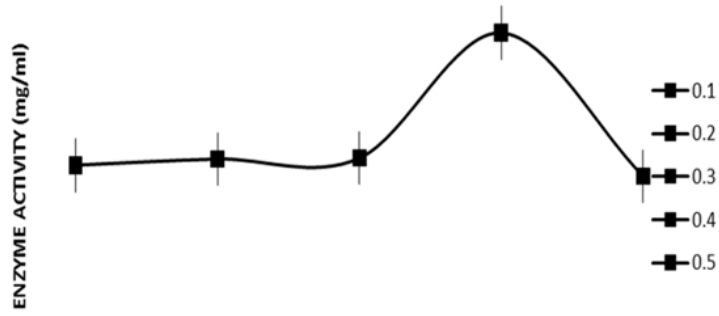

ENZYME CONCENTRATION (mg/ml)

Fig. 9: Effect of Enzyme concentration on enzyme activity

Effect of Enzyme concentration on the papain like protease purified from betel leaves was done at different enzyme concentrations $0.1,0.2,0.3,0.4$ $0.5 \mathrm{mg}$ per $\mathrm{ml}$. Maximum activity was at $0.4 \mathrm{mg} / \mathrm{ml}$.

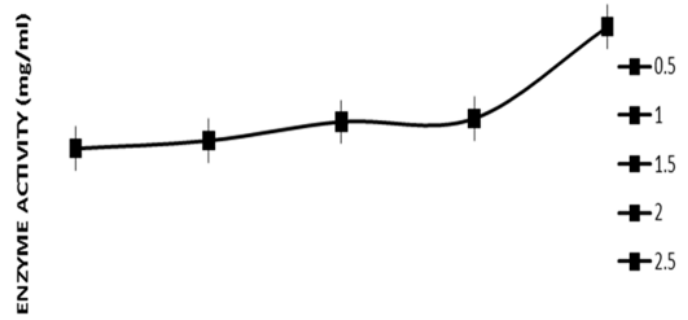

SUBSTRATE CONCENTRATION (mg/ml)

Fig. 10: Effect of Substrate concentration on enzyme activity

Effect of Substrate concentration on the papain like protease purified from betel leaves was done at $0.1,0.2,0.3,0.4$ and $0.5 \mathrm{ml}$ volumes of $2 \%$ casein Maximum activity was at $2.5 \mathrm{mg} / \mathrm{ml}$.

\subsection{Kinetic parameters:}

The activity of papain like enzyme from betel leaves at optimum $\mathrm{pH}$ and temperature was determined employing different concentrations of casein and the reciprocal of the enzyme activity was plotted versus reciprocal of substrate concentration. The Vmax and $\mathrm{Km}$ values of purified enzyme at $\mathrm{pH} 10$ and $60^{\circ} \mathrm{C}$ were determined as $4 \times 10^{-3} \mathrm{M}$ and $54 \mu \mathrm{mol} / \mathrm{min} / \mathrm{mg}$ respectively (figure $11 \mathrm{a} \&$ b). The low $\mathrm{km}$ value ensures high affinity to the substrate enabling proper cleansing activity.

Detergent Activity of Papain-Like Enzyme: A single, versatile and universally applicable enzyme is the endeavour by various researchers for the past 20 years and also improving the known detergents $[17,1]$. As proteases have cleansing property the detergent activity of papain like enzyme was analysed.

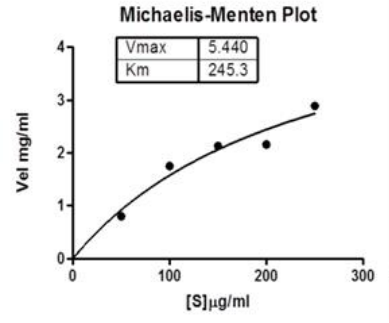

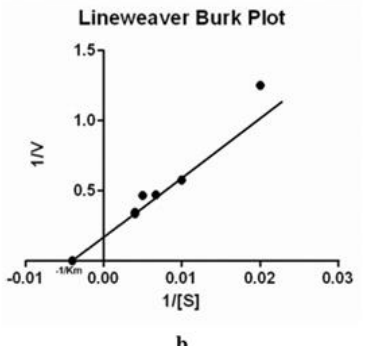

b
Fig. 11: Michaelis-Menten and Lineweaver Burk Plot for the papain like enzyme

M-M plot and line weaver Burk plot for papain-like enzyme from betel leaves using different concentration of casein as substrate. The reciprocals of velocity were plotted against variable substrate concentrations. Note: LB plot was plotted using Graph pad Prism software.

The stained cloth pieces were left overnight and the subsequent day were soaked with enzyme isolated from betel leaves along with detergents. Then the clothes were observed for presence or absence of stains (table 2).

Table 2: Detergent activity of papain

\begin{tabular}{|c|c|c|c|c|c|c|c|}
\hline Stain & mark & $\begin{array}{c}\text { Suff(No } \\
\text { enzymes) }\end{array}$ & $\begin{array}{c}\text { Surf(No } \\
\text { enzymes) }\end{array}$ & $\begin{array}{c}\text { Henko } \\
\text { (Oxy power) }\end{array}$ & $\begin{array}{c}\text { Henko } \\
\text { (Oxy power) }\end{array}$ & $\begin{array}{c}\text { Tide } \\
\text { (Enzyme) }\end{array}$ & $\begin{array}{c}\text { Tide } \\
\text { (Enyyme) }\end{array}$ \\
\hline & & Control & Test & Control & Test & Control & Test \\
\hline chocolate stain & 1 & $-v e$ & tve & -ve & tve & -ve & +ve \\
\hline tea stain & 2 & $-v e$ & tve & $-v e$ & tve & -ve & tve \\
\hline blood stain & 3 & $-v e$ & tve & -ve & tve & -ve & +ve \\
\hline
\end{tabular}

The detergent activity of papain like enzyme was analyzed. The stained cloth pieces were left overnight and the subsequent day were soaked with detergents. The clothes were observed for absence or presence of stains. Washing was done with Controls and Test samples. Controls were kept with only commercial liquid detergents; test was prepared with addition of papain like protease isolated from Betel leaves to the commercial liquid detergent. Stained cloths washed with test showed effective destaining when compared with control, so test where marked as +ve and controls as $-\mathrm{ve}$.

It was identified that after adding the papain like enzyme solution the stains were removed much better than that of those samples where papain like enzyme was not added hence it is affirmed that papain enhances detergent activity (figures 12).

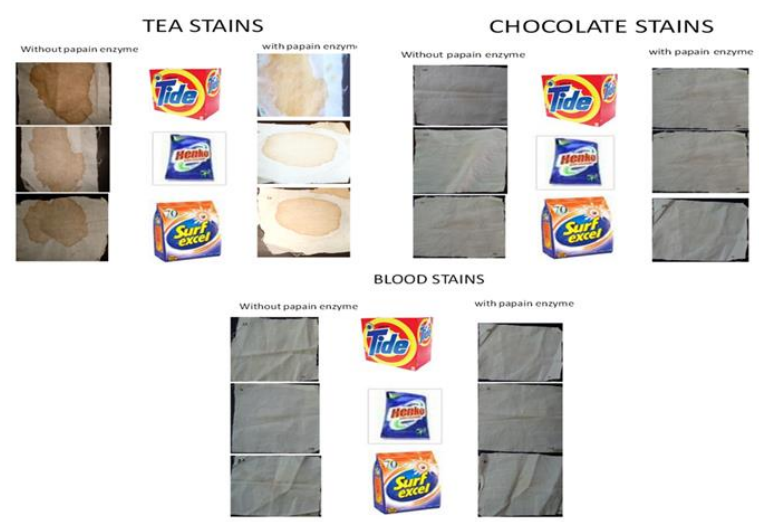

Fig. 12: Removal of tea, chocolate and blood stains using papain like enzyme from betel leaves

Pieces of populine cloth were overnight stained with tea, chocolate and blood stains. They were washed with three different detergents TIDE, HENKO, SURF EXCEL. Three controls were set without papain like protease. For the test samples Papain like protease was added. Test samples showed effective destaining when compared with controls.

\subsection{Compatibility with detergents and de-staining property:}

For the possible commercial exploitation of papain in detergent industry, the isolated papain like enzyme was tried for its compatibility with detergents of common use. The enzyme in the presence of detergent solution (called as buffered detergent) revealed that when used in water, Tide, Henko and Surf showed lesser compatibility when compared with the buffered detergent solution as depicted in figure 13 .

$\square$ DETERGENT

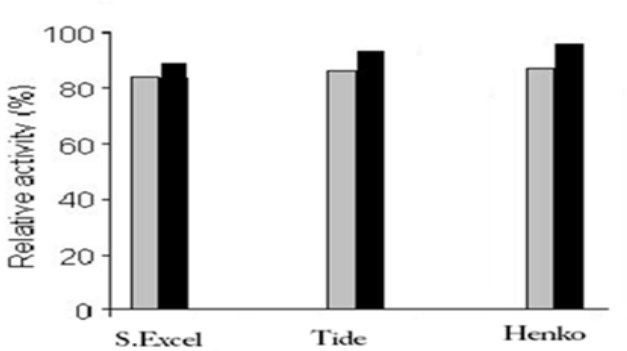

Fig. 13: Compatibility of papain like enzyme isolated from betel leaves with commercial detergents.

For the possible commercial exploitation of papain in detergent industry, the isolated papain like enzyme was verified for its compatibility with 3 detergents of common use. The enzyme incubated with detergent solution (called as buffered detergent) has shown that when used in water, Tide, 
Henko and Surf showed less compatibility as against buffered detergent solution.

Among the three detergents used to determine the detergent activity of papain two of them i.e. Tide and Henko already contained the enzyme as quoted by their manufacturers. The detergent capacity of the controls was found to be inferior to that supplemented with papain like enzyme. This shows that the enzyme fortifies the action of the detergents. Chocolate, tea and blood stains were not completely removed with the detergent solutions but the detergent solution supplemented with enzyme was completely removes the stains. This is a valid result suggesting the use of enzyme in detergent industry.

The present study thus reveals that papain like enzyme isolated from Betel leaves is compatible with local detergents suggesting its potential as a detergent supplement for improved washing.

\section{Acknowledgement}

Lab facilities were provided by the Department of Biochemistry and Bioinformatics, Institute of Science, GITAM Deemed to be University.

\section{References}

[1] Siezen, R. J., \& Leunissen, J. A., "Subtilases: the superfamily of subtilisin-like serine proteases", Protein Science, 6(3), (1997), 501523.

[2] Duffy, J. I., \& Gutcho, S., "Chemicals by enzymatic and microbial processes: recent advances [USA]", Noyes Data Corp, (1980)

[3] Cohen, L. W., Coghlan, V. M., \& Dihel, L. C., "Cloning and sequencing of papain-encoding cDNA", Gene, 48(2), (1986), 219-227.

[4] Drenth, J., J. N. Jansonius, R. Koekoek, H. M. Swen, and B. G. Wolthers, "Structure of papain" Nature, 218, (1968), 929-932.

[5] Drenth, J., Kalk, K. H., \& Swen, H. M., "Binding of chloromethyl ketone substrate analogs to crystalline papain", Biochemistry, 15(17), (1976), 3731-3738.

[6] Varughese, K. I., Ahmed, F. R., Carey, P. R., Hasnain, S., Huber, C. P., \& Storer, A. C., "Crystal structure of a papain-E-64 complex", Biochemistry, 28(3), (1989), 1330-1332.

[7] Schechter, I., \& Berger, A., "On the size of the active site in proteases. I. Papain”, Biochem. Biophys. Res. Commun, 27, (1967), 157-162.

[8] Lopes, M. C., Mascarini, R. C., da Silva, B. M. C. G., Flório, F. M., \& Basting, R. T., "Effect of a papain-based gel for chemomechanical caries removal on dentin shear bond strength", Journal of Dentistry for Children, 74(2), (2007), 93-97.

[9] Burrows, D. L., Nicolaides, A., Rice, P. J., Dufforc, M., Johnson, D. A., \& Ferslew, K. E., "Papain: a novel urine adulterant", Journal of analytical toxicology, 29(5), (2005), 275-295.

[10] Anson, M. L., "The estimation of pepsin, trypsin, papain, and cathepsin with hemoglobin", The Journal of General Physiology, 22(1) (1938)79-89.

[11] Liener, I. E., \& Kakade, M. L., "Protease inhibitors in" Toxic constituents in plant foodstuffs", Ed. Liener, IE, (1969), 7.

[12] Arnon, R., "Papain", Methods in enzymology, 19, (1970), 226-244.

[13] Laemmli, U. K., "Cleavage of structural proteins during the assembly of the head of bacteriophage T4", Nature, 227(5259), (1970), 680-685.

[14] Dubey, V. K., Pande, M., Singh, B. K., \& Jagannadham, M. V., "Papain-like proteases: Applications of their inhibitors", African Journal of Biotechnology, 6(9), (2007), 1077-1086.

[15] Adinarayana, K., Raju, K. B., \& Ellaiah, P., "Investigations on alkaline protease production with B. subtilis PE-11 immobilized in calcium alginate gel beads", Process Biochemistry, 39(11), (2004), 1331-1339.

[16] Wahyuntari, B., Mubarik, N. R., \& Anggaran, M., "Isolation and selection of alkaline proteolytic bacteria from leather processing waste and enzyme characterization", Biotropia-The Southeast Asian Journal of Tropical Biology, 22, (2004).

[17] Phadatare, S. U., Deshpande, V. V., \& Srinivasan, M. C., "High activity alkaline protease from Conidiobolus coronatus (NCL 86.8. $20)$ : enzyme production and compatibility with commercial detergents", Enzyme and microbial technology, 15(1), (1993), 72-76. 